\title{
DETERMINAN VOLUNTARY NONFINANCIAL DISCLOSURE PADA PERUSAHAAN DI INDONESIA
}

\author{
Rio Pramudhana Faizal \\ Universitas Sebelas Maret \\ e-mail: riopramudhana@gmail.com \\ Agung Nur Probohudono \\ Universitas Sebelas Maret \\ e-mail: probohudono.uns@gmail.com
}

\begin{abstract}
This study examines the impact of ownership structure and tax disclosure on voluntary nonfinancial disclosure in Indonesia. Ownership structure is characterized by public ownership and foreign ownership. Tax disclosure is part of the mandatory disclosure. Voluntary nonfinancial disclosure is proxied by an agregated disclosure score of strategic disclosure, labor disclosure, environment disclosure and social disclosure. This study examines of voluntary nonfinanial disclosure practices in the annual reports of listed companies in Indonesia from 2009 to 2012. The sample of this study are 102 listed companies in Indonesia in the period of 2009 to 2012. Total sample is 408 annual report. The technique used is purposive sampling technique. The results show that foreign ownership, public ownership, tax disclosure, size and Asset turnover are associated with voluntary nonfinancial disclosure in Indonesian listed companies.
\end{abstract}

Keywords: Agency theory, ownership structure, tax disclosure, voluntary nonfinancial disclosure.

\begin{abstract}
Abstrak
Penelitian ini menjelaskan pengaruh dari ownership structure dan tax disclosure pada voluntary nonfinancial disclosure di Indonesia.Ownership structureterdiri dari public ownership dan foreign ownership. Tax disclosure yang merupakan bagian dari mandatory disclosure. Voluntary nonfinancial disclosure diproksikan oleh jumlah skor dari strategic disclosure, labor disclosure, environment disclosure dan social disclosure. Penelitian ini menjelaskan praktik voluntary nonfinanial disclosure pada annual report perusahaan yang terdaftar di BEI tahun 2009-2012. Sampel dari penelitian ini adalah 102 perusahaan yang terdaftar di BEI tahun 2009-2012. Total annual report yang dijadikan sampel adalah 408. Teknik pengambilan sampel menggunakan teknik purposive sampling. Hasil penelitian menunjukan bahwa Foreign ownership, public ownership, tax disclosure, size dan Asset turnover berhubungan dengan voluntary nonfinancial disclosure pada perusahaan-perusahaan yang terdaftar di BEI.
\end{abstract}

Kata Kunci: agency theory, ownership structure, tax disclosure, voluntary nonfinancial disclosure.

\section{PENDAHULUAN}

Corporate voluntary discosure dan faktorfaktor yang menentukannya telah menarik bagi para peneliti akuntansi sejak tahun 1970an (Chau dan Gray 2010). Penelitian mengenai voluntary disclosure telah banyak mengalami perkembangan dan pada setiap negara atau wilayah akan menunjukan hasil yang beragam. Perbedaan tersebut dikarenakan masing-masing negara atau wilayah tersebut memiliki karakteristik yang berbeda, misalkan adanya pemberian insentif kepada manajer yang berbeda-beda. Menurut Eng dan Mak (2003) ketika perusahaan memberikan insentif kepada manajer untuk menginformasikan voluntary disclosure merupakan salah satu 
masalah yang menarik dalam penelitian. Manajer sebagai agent akan berusaha untuk memuaskan pemegang saham atau principal. Pemegang saham akan memberikan insentif sesuai dengan kontrak yang disepakati antara manajer dan pemegang saham. Namun, ketika terjadi kontrak antara pemegang saham dan manajer akan menimbulkan potensi adanya konflik kepentingan antara pemegang saham dan manajer (Jensen dan Meckling 1976). Konflik kepentingan tersebut terjadi karena manajer dan pemegang saham ingin memaksimalkan kesejahteraan masing-masing. Untuk mengurangi adanya konflik kepentingan maka perusahaan akan berusaha melakukan pengungkapan informasi publik, termasuk disclosure dalam annual report (Zhegal dan Ahmed 1990). Disclosure dianggap sebagai solusi yang tepat untuk mengurangi konflik kepentingan karena disclosure memuat informasi lengkap baik mengenai informasi financial dan nonfinancial. Dengan adanya disclosure, pemegang saham akan dapat memantau kinerja manajer melalui informasi yang diungkapkan baik informasi financial maupun nonfinancial.

Menurut Ho dan Taylor (2013) secara umum, disclosure meliputi informasi financial dan nonfinancial, informasi yang berkaitan dengan direksi, dan informasi yang terkait dengan masa depan. Informasi financial merupakan informasi yang berkaitan dengan keuangan perusahaan, namun informasi financial saat ini tidak lagi menjadi acuan satu-satunya bagi investor untuk melakukan investasi. Robb, Single, dan Zarzeski (2001) berpendapat bahwa investor dan analis keuangan melihat informasi nonfinancial untuk melihat kemampuan jangka panjang manajer dalam mengelola sumber daya secara efektif dan efisien. Informasi nonfinancialb dianggap oleh investor sebagai informasi yang dipertimbangkan untuk melakukan investasi selain informasi financial. Karena itulah salah satu tujuan dalam penelitian mengenai annual report perusahaan adalah untuk memperbaharui pemahaman mengenai faktor-faktor yang menjelaskan nonfinancial disclosure (Robb et al. 2001). Dalam penelitian ini memiliki tujuan untuk mengetahui seberapa tingkat penerapan voluntary nonfinancial disclosure pada perusahaan di Indonesia dan mengetahui hubungan antara ownership structure dan tax disclosure dengan tingkat voluntary nonfinancial disclosure.

Di U.S, American Institute of Certified Public Accountants (AICPA) telah membentuk komite khusus dalam hal pelaporan keuangan yang disebut Jenkins Committe. Jenkins Committe merekomendasikan kepada perusahaaan di U.S untuk menginformasikan nonfinancial disclosure. Nonfinancial disclosure yang dimaksud oleh Jenkins Committe ialah informasi kualitatif yang terdapat dalam annual report namun diluar laporan keuangan dan footnotes yang berhubungan dengan laporan keuangan (Robb et al. 2001). Nonfinancial disclosure tersebut dapat berupa keamanan dan kualitas produk, informasi sosial serta aktivitas lingkungan. Selain itu mereka menginginkan informasi mengenai etika, hubungan dengan karyawan dan masyarakat.

Di dalam standar akuntansi keuangan di Indonesia, nonfinancial disclosure seperti pengungkapan informasi mengenai tanggung jawab perusahaan terhadap lingkungan memang belum diwajibkan, tetapi dislosure ini sudah diwajibkan di dalam aturan Bapepam LK 2006, UU PT 40 th 2007, dan PP No. 47 th 2012. Pemerintah menerbitkan PP No. 47 th 2012 yang mengatur tanggung jawab perusahaan terhadap lingkungan pada perusahaan terbatas di Indonesia. Pengungkapan informasi mengenai tanggung jawab perusahaan terhadap lingkungan di pengaruhi oleh kondisi suatu negara. Indonesia merupakan negara berkembang sehingga tingkat nonfinancial disclosure cenderung lebih rendah dibandingkan negara maju. Perusahaan di negara maju akan mempertimbangkan biaya dan manfaat yang akan diperoleh ketika mereka memutuskan untuk mengungkapkan informasi sosial dan lingkungan. Bila manfaat yang akan diperoleh dengan pengungkapan informasi tersebut lebih besar dibandingkan biaya yang dikeluarkan untuk mengungkapkannya maka perusahaan akan dengan suka- 
rela mengungkapkan informasi tersebut. Disclosure baik mengenai informasi financial maupun nonfinancial akan dilaporkan dalam annual report, sustainability report, ataupun laporan perusahaan lainya. Menurut Diyanti (2010), annual report menjadi salah satu bahan untuk pengambilan keputusan dan juga menjadi standar pertanggung jawaban manajemen atas sumber daya yang telah dikelola bagi investor.

Ada dua pembagian pengungkapan dalam annual report, yaitu mandatory disclosure (pengungkapan wajib) dan voluntary disclosure (pengungkapan sukarela). Mirfazli (2008) mendefinisikan mandatory disclosure sebagai informasi yang harus diungkapkan sebagai konsekuensi dari adanya ketentuan perundang-undangan, pasar saham, komisi bursa saham atau peraturan akuntansi dari pihak yang berwenang, sedangkan Meek, Gray, dan Roberts (1995) mendefinisikan voluntary disclosure sebagai pengungkapan yang melebihi dari persyaratan, mewakili pilihan bebas dari manajemen perusahaan untuk memberikan informasi akuntansi dan lain yang dianggap relevan dengan keputusan, kebutuhan pengguna annual report mereka. Setiap negara memiliki peraturan yang berbeda mengenai hal apa saja yang menjadi mandatory disclosure. Di Indonesia, Status perusahaanyang sudah go public diwajibkan untuk menyampaikan annual report perusahaanya kepada Badan Pengawas Pasar Modal (BAPEPAM).

Annual report merupakan salah satu laporan yang diwajibkan untuk disampaikan sesuai dengan peraturan Bapepam-LK No. X.K.6 tentang Kewajiban Penyampaian Laporan Tahunan bagi Emiten dan Perusahaan Publik. Setiap perusahaan diwajibkan secara berkala atau periodik menyampaikan annual report kepada Bapepam-LK. Salah satu disclosure yang wajib diungkapkan adalah tax disclosure. Tax disclosure dapat didefinisikan sebagai informasi mengenai pajak yang harus diungkapkan dalam annual report dan diatur oleh peraturan pemerintah.

Menurut Gisbert dan Navallas (2013), Mandatory Disclosure saat ini dianggap kurang sempurna karena tidak selalu memberikan informasi yang dibutuhkan oleh pengguna. Dengan adanya kekurangan tersebut menyebabkan organisasi akuntansi internasional dan regulator untuk meningkatkan informasi yang diungkapkan sukarela dalam laporan tahunan (Beattie et al.2004).

Menurut Schuster dan O'Connell (2006) saat ini voluntary disclosure telah tumbuh menjadi suatu hal yang sangat penting dalam pasar modal. Ketika perusahaan memutusan untuk terlibat dalam voluntary disclosure mungkin hal tersebut merupakan respon dari adanya inovasi, globalisasi atau perubahan dalam bisnis dan lingkungan pasar modal perusahaan (Healy dan Palepu 2001). Dengan adanya voluntary disclosure tersebut diharapkan dapat memberikan informasi yang lengkap dan transparansi oleh pemakai laporan tahunan (Meek et al. 1995). Selain itu,menurut Lang dan Lundholm (1996) pengungkapan (disclosure) akan mengurangi biaya yang dikeluarkan pengguna eksternal untuk memperoleh informasi tentang perusahaan.

Dengan adanya peningkatan dislosure, maka investor akan mendapat keuntungan dalam perencanaan investasi dengan mengurangi ketidakpastian dalam pengembalian investasi dan bagi perusahaan akan mampu mengurangi biaya modal sehingga nilai perusahaan pun akan mengalami peningkatan, sedangkan bagi pemerintah dengan adanya peningkatan pengungkapan akan meningkatkan keterbukaan informasi pula (Hassan et al. 2011). Khan (2012) memaparkan bahwa jaminan perlindungan terhadap pemegang saham minoritas akan tercapai jika adanya peningkatan transaparansi informasi antara principal dan agent.

Beberapa penelitian menemukan adanya hubungan antara disclosure dan ownership structure. Penelitian mengenai disclosure akuntansi terus-menerus berkembang dan menunjukkan pentingnya aspek corporate governance perusahaan seperti ownership structure (Chau dan Gray 2002; Eng dan Mak 2003). Meek et al. (1995) melakukan penelitian berkaitan dengan jenis informasi yang diungkapkan pada perusahaan multi- 
nasional dikawasan UK, US dan Eropa, hasil dari penelitian tersebut diperoleh kesimpulan bahwa perusahaan multinasional berskala besar menyediakan pengungkapan informasi berkenan dengan informasi financial dan nonfinancial, sedangkan informasi berkenaan dengan strategi lebih khusus diungkapkan oleh perusahaan di negara Eropa terlepas dari besarnya usaha atau jenis industri yang dilakukan.

Dalam penelitianya Robb et al. (2001) meneliti hubungan antara praktik nonfinancial disclosure dan karakteristik perusahaan. Dalam penelitianya menyimpulkan bahwa nonfinancial disclosure telah menjadi hal yang penting, tidak hanya financial disclosure saja dan nonfinancial disclosure menjadi hal penting untuk dilakukan penelitian terutama untuk mengetahui apa yang menjadi determinan dari nonfinancial disclosure.

\section{KAJIAN TEORITIS DAN PENGEMBANGAN HIPOTESIS}

\section{Agency Theory}

Jensen dan Meckling (1976) mendefinisikan hubungan keagenan sebagai kontrak antara satu orang atau lebih (principal, yaitu shareholder) yang menunjuk orang lain (agent, yaitu manajer) dalam melaksanakan jasa untuk kepentingan principal. Hubungan agensi ada ketika salah satu pihak (principal) menyewa pihak lain (agent) untuk melaksanakan suatu jasa dan dalam melakukan hal itu, principal mendelegasikan wewenang untuk membuat keputusan kepada agent tersebut (Govindarajan dan Anthony 2001).

Menurut Battacherjee (2012) Agency theory menjelaskan hubungan antara dua belah pihak yaitu agent dan principal yang memiliki ketidaksesuaian tujuan, dan dengan adanya teori ini untuk meminimalkan efek dari ketidaksesuaian tujuan kedua belah pihak tersebut dengan menentukan kondisi dan kontrak yang optimal. Agency theory menunjukan adanya masalah insentif yang dapat disebabkan karena adanya pemisahan kepemilikan dan pengendalian, sehingga menyebabkan terjadinya perbedaan kepentingan antara kontrak yang dibuat oleh pricipal dan agent dalam suatu perusahaan (Colgan 2001; Ahmed 2009; $\mathrm{Su}$ et al. 2010). Jensen dan Meckling (1976) berpendapat bahwa dengan adanya hubungan keagenan tersebut terkadang akan menimbulkan masalah antara manajer sebagai agent dan pemegang saham sebagai principal.

Fama dan Jensen (1983) memaparkan masalah keagenan muncul dikarenakan adanya konflik kepentingan antara agent dan principal dalam hal agency cost dimana kontrak keduanya biasanya tidak tertulis. Selain itu, masalah keagenan yang timbul ini juga disebabkan adanya asimetri informasi antara pihak principal dan agent.

Asimetri informasi antara manajer dan investor merupakan permasalahan yang sering dihadapi di dalam suatu perusahaan publik dan hal tersebut yang menyebabkan peningkatan permintaan atas pelaporan dan disclosure informasi keuangan perusahaan (Healy dan Palepu 2001). Dalam kaitanya dengan hubungan keagenan, masalah asimetri informasi antara pricipal dan agent dapat terjadi karena agent memiliki keuntungan informasi yang lebih mengenai perusahaan (Probohudono et al. 2013a).

Menurut Scott (2003), ada dua bentuk asimetri informasi, yaitu: 1) Adverse Selection. Merupakan bentuk asimetri informasi, dimana pihak yang satu mempunyai keunggulan informasi dibandingkan dengan pihak yang lain dalam transaksi bisnis atau usaha, namun tidak bersedia menginformasikanya. 2) Moral Hazard. Merupakan bentuk asimetri informasi, dimana pihak yang satu dalam suatu transaksi bisnis atau usaha dapat mengamati tindakan mereka secara penuh, namun pihak lainnya tidak dapat melakukan hal tersebut.

Jensen dan Meckling (1976), memaparkan bahwa pemegang saham yang menanamkan investasinya pada perusahaan menginginkan adanya pengembalian yang lebih besar dan cepat atas apa yang telah diinvestasikan, sedangkan manajer dalam menjalankan perusahaan menginginkan kepentingannya diakomodasi oleh pemegang saham dengan pemberian kompensasi atau insentif yang sebesar-besarnya atas kinerja 
manajer tersebut. Manajer mungkin memiliki keuntungan karena memiliki informasi yang lebih dan akan memanfaatkan informasi tersebut untuk kesejahteraan pribadi (Alchian dan Woodward 1988).

Menurut Ugurlu (2000), ketika agent atau manajemen lebih memilih bertindak untuk mengejar kepentingan pribadi dan cenderung merugikan principal atau pemegang saham, maka munculah agency cost. Menurut Ang et al. (2000) saat terjadinya ketidakselarasan antara manajer dan para pemegang saham, maka disitulah akan muncul agency cost.

Jensen dan Meckling (1976) membagi agency cost sebagai berikut: 1) The monitoring expenditures by the principal. Merupakan biaya yang dikeluarkan oleh prinsipal berupa insentif manajemen untuk pemantauan dan memastikan agent selalu bertindak sesuai kepentingan prinsipal sebagai akibat dari adanya pendelegasian sebagian wewenang dari principal kepada agent. 2) The bonding expenditures by the agent. Merupakan biaya yang harus ditanggung oleh agent untuk menetapkan dan mematuhi mekanisme yang menjamin bahwa agent tidak akan melakukan tindakan tertentu yang akan merugikan principal. 3) The residual loss. Merupakan pengurangan kesejahteraan yang dialami oleh principal akibat adanya perbedaan keputusan yang diambil antara agent dan principal.

Prosedur pengendalian yang efektif dibutuhkan oleh perusahaan untuk mengatasi adanya masalah keagenan (Fama dan Jensen 1983). Voluntary dan mandatory disclosure akan membantu stakeholders dalam mengurangi adanya masalah dalam asimetri informasi (Probohudono et al. 2013b). Manajer akan mengungkapkan informasi sosial ketika seorang manajer tersebut ingin meningkatkan kesejahteraan mereka, yaitu ketika manfaat dari pengungkapan lebih besar daripada agency cost yang terkait. Tindakan manajer yang diharapkan oleh pemegang saham ialah untuk memaksimalkan keuntungan pemegang saham (Berle dan Means 1932). Seorang agent (manajer) akan mengungkapkan informasi secara sukarela karena kepentingan pribadi mereka tentang reputasi dan remunerasi (Healy dan Palepu 2001).

Dalam praktik voluntary disclosure, menurut Barako (2007) agency theory dapat terjadi ketika manajer yang seharusnya memiliki akses informasi yang lebih baik ke dalam perusahaan tidak mengungkapkan informasi tersebut secara kredibel dan handal, hal tersebut dikarenakan manajer ingin memuaskan kepentingan mereka sendiri yang mengakibatkan tingginya biaya modal dan rendahnya nilai investasi pemegang saham.

Kaitanya dengan corporate governance, menurut Jensen dan Meckling (1976) transparansi dalam informasi akan mengurangi konflik keagenan antara shareholder dan manajer. Taylor et al. (2008) mengatakan dengan konsep dari agency theory, corporate governance merupakan cara terbaik untuk mengurangi perilaku manajer yang oportunistic. Agency cost dapat dikurangi dengan adanya mekanisme corporate governance (Jensen dan Meckling 1976; Colgan 2001). Mekanisme governance dilakukan untuk membatasi biaya agensi yang timbul dari kegiatan menyimpang yang dilakukan oleh manajer (Taylor et al.2008)

Agency Theory dapat digunakan sebagai kerangka kerja konseptual untuk menjelaskan perilaku pengungkapan manajerial dalam kaitannya dengan dampak pajak dan strategi minimalisasi pajak perusahaan (Taylor et al. 2011). Kepatuhan wajib pajak tidak hanya dipengaruhi oleh hukum pajak itu sendiri tetapi juga oleh pelaksanaannya melalui otoritas pajak (Eichfelder dan Kegels 2012).

\section{Tax Disclosure}

Kepatuhan wajib pajak merupakan faktor penting dalam upaya pemerintah untuk meningkatkan penerimaan pajak, oleh karena itu perlu adanya kajian mengenai faktor-faktor yang dapat mempengaruhi wajib pajak khususnya wajib pajak badan. Sesuai dengan Peraturan Badan Pengawas Pasar Modal dan Lembaga Keuangan (Bapepam-LK) No. X.K.6 tentang Kewajiban Penyampaian Laporan Tahunan bagi Perusahaan Publik, 
setiap perusahaan publik secara berkala atau periodik wajib menyampaikan laporan tahunan kepada Bapepam-LK. Dalam peraturan Bapepam-LK No. X.K.6 dijabarkan checklist mengenai pengungkapanyang berhubungan dengan perpajakan. Hal-hal yang harus diungkapkan dalam annual report perusahaan publik adalah: 1) Penjelasan hubungan antara beban (penghasilan) pajak dan laba akuntansi. 2) Rekonsiliasi fiskal dan perhitungan beban pajak kini. 3) Pernyataan bahwa Laba Kena Pajak (LKP) hasil rekonsiliasi dijadikan dasar dalam pengisian SPT Tahunan PPh Badan. 4) Rincian aset dan liabilitas pajak tangguhan yang diakui pada laporan posisi keuangan untuk setiap periode penyajian, dan jumlah beban (penghasilan) pajak tangguhan yang diakui pada laporan laba rugi apabila jumlah tersebut tidak terlihat dari jumlah asset atau liabilitas pajak tangguhan yang diakui pada laporan posisi keuangan. 5) Pengungkapan ada atau tidak ada sengketa pajak.

\section{Pengembangan Hipotesis Foreign Ownership}

Menurut Ho dan Taylor (2013) pada penelitiannya di perusahaan China berpendapat bahwa investor asing telah berperilaku sebagai agen pengawas eksternal yang efektif. Perusahaan di China dengan kepemilikan asing cenderung tunduk atau patuh terhadap pengawas eksternal, sehingga perusahaan di China yang memiliki kepemilikan asing mempunyai tingkat voluntary disclosure yang relatif lebih besar.

Hassan (2013) berpendapat bahwa kehadiran kepemilikan asing sebagai aspek mekanisme kepemilikan dapat diindikasi menyebabkan meningkatkan tingkat voluntary disclosure di United Arab Emirates (UAE). Peningkatan kepemilikan asing pada perusahaan diharapkan dapat meningkatkan penyediaan informasi yang berkualitas dan dapat memotivasi manajerial untuk memberikan informasi tambahan terkait dengan voluntary disclosure. Berdasarkan uraian di atas, maka penelitian ini dapat dikembangkan hipotesis:
$\mathrm{H}_{1}$ : Foreign ownership berpengaruh signifikan positif terhadap voluntary nonfinancial disclosure pada perusahaan yang terdaftar di BEI.

\section{Public Ownership}

Baroko (2007) dalam penelitianya menemukan adanya hubungan positif antara tingkat dislosure dengan pubic ownership. Hasil tersebut menunjukkan bahwa ownership structure dapat dijadikan sebagai landasan dalam mekanisme pengawasan yang baik untuk mendorong perusahaan menyediakan informasi yang lengkap dan relevan. Hardiningsih (2008) mengemukakan bahwa adanya perbedaan dalam proporsi saham yang dimiliki oleh masyarakat dapat mempengaruhi kelengkapan pengungkapan oleh perusahaan. Hal ini karena semakin banyak pihak yang membutuhkan informasi tentang perusahaan, semakin banyak pula detail-detail butir yang dituntut untuk dibuka dan dengan demikian pengungkapan perusahaan semakin luas. Berdasarkan uraian di atas, maka penelitian ini dapat dikembangkan hipotesis:

$\mathrm{H}_{2}$ : Public ownership berpengaruh positif terhadap voluntary nonfinancial disclosure pada perusahaan yang terdaftar di BEI.

\section{Tax Disclosure}

Pada praktik di Indonesia, beberapa ketentuan Tax disclosure merupakan bagian dari mandatory disclosure. Tax disclosure dapat didefinisikan sebagai informasi mengenai pajak yang harus diungkapkan dalam annual report dan diatur oleh peraturan pemerintah. Peraturan yang diterapkan dapat berubah setiap saat sesuai dengan kebijakan pemerintah. Karena itu perusahaan akan menyewa akuntan pajak profesional untuk bertanggung jawab dalam tax disclosure sesuai dengan peraturan yang ada.

Dalam penelitian yang dilakukan Taylor et al. (2011) menunjukan bahwa withholding taxes berpengaruh positif dan berhubungan terhadap pola disclosure, sedangkan foreign sourced income dan tax haven ber- 
pengaruh negatif terhadap pola disclosure. Berdasarkan hal tersebut dapat ditarik kesimpulan bahwa struktur pajak internasional dapat mempengaruhi pola corporate disclosure.

Lundholm (2003) berpendapat bahwa meskipun mandatory disclosure adalah melihat ke belakang dan karena itu tidak memiliki konten informasi, namun meningkatkan kualitas voluntary disclosure. Berdasarkan uraian di atas, maka penelitian ini dapat dikembangkan hipotesis:

$\mathrm{H}_{3}$ : Tax disclosure berpengaruh positif terhadap voluntary nonfinancial disclosure pada perusahaan yang terdaftar di BEI.

\section{Size}

Ukuran perusahaan telah terbukti menjadi variabel yang berpengaruh dalam menjelaskan perbedaan praktik pengungkapan antar perusahaan (Wallace et al. 1994). Perusahaan besar cenderung menginginkan tingka tdisclosure yang lebih tinggi daripada perusahaan kecil (Meek et al. 1995). Disclosure yang lebih mendetail membutuhkan biaya yang mahal sehingga perusahaan kecil tidak mampu untuk menjangkaunya.

Perusahaan besar berdampak lebih besar terhadap masyarakat dan oleh karena itu biasanya memiliki stakeholder yang lebih banyak sehingga memberikan tekanan yang lebih besar pula kepada perusahaan (Knox et al., 2005). Selain itu, perusahaan besar memiliki sumber daya yang memadai untuk mengumpulkan, menganalisis, dan menyajikan data terkait aktivitas keberlanjutan (Oliveira 2010). Berdasarkan uraian di atas, maka penelitian ini dapat dikembangkan hipotesis:

$\mathrm{H}_{4}$ : Size berpengaruh positif terhadap voluntary nonfinancial disclosure pada perusahaan yang terdaftar di BEI.

\section{Asset Turn Over}

Rasio asset turn over merupakan salah satu cara untuk mengukur agency cost. Asset turn over merupakan rasio yang digunakan untuk mengukur seberapa efisiensi seluruh aktiva perusahaan digunakan untuk menunjang kegiatan penjualan (Van Horne dan Wachowicz 2007).
Asset turn over diukur melalui penjualan tahun berjalan dibagi dengan total asset (Ang et al. 2000). Menurut Ang et al. (2000) rasio asset turn over dapat mengukur bagaimana efektifitas persusahaan dalam mengelola aset perusahaan. Perusahaan dengan rasio asset turn over yang rendah menunjukan agency cost yang positif (Ang et al. 2000). Agency cost ini dapat muncul dikarenakan adanya pengambilan keputusan yang salah, usaha yang dilakukan kurang sehingga penjualan menjadi rendah dan pembelian aset yang tidak produktif (Ang et al. 2000). Berdasarkan uraian di atas, maka penelitian ini dapat dikembangkan hipotesis:

$\mathrm{H}_{5}$ : Asset turn over berpengaruh positif terhadap voluntary nonfinancial disclosure pada perusahaan yang terdaftar di BEI.

\section{METODE PENELITIAN Populasi, sampel dan Teknik Pengambilan Sampel}

Populasi dari penelitian ini meliputi seluruh perusahaan di Indonesia yang terdaftar dalam Bursa Efek Indonesia periode tahun 20092012. Teknik pengambilan sampel yang digunakan adalah teknik purposive sampling dengan tipe pengambilan sampel berdasarkan pertimbangan tertentu (judgment sampling). Dalam penelitian ini, kriteria yang dikehendaki adalah perusahaan yang terdaftar di Bursa Efek Indonesia, menyampaikan laporan berturut-turut dari tahun 2009-2012 dan menyediakan data yang dibutuhkan untuk variabel penelitian.

Dalam penelitian ini terdapat 469 perusahaan yang terdaftar di Bursa Efek Indonesia. Atas jumlah tersebut, 102 perusahaan setiap periode terpilih sebagai sampel penelitian dengan kriteria sebagai berikut: a) Perusahaan-perusahaan yang terdaftar di Bursa Efek Indonesia periode 2009-2012 dan menyampaikan annual report. b) Perusahaan di Bursa Efek Indonesia yang menyampaikan laporan secara berturut-turut tahun 2009-2012. c) Perusahaan menyajikan data untuk pengukuran variabel ownership structure secara jelas. 


\section{Data dan Sumber Data}

Data yang digunakan dalam penelitian ini adalah data sekunder yang diperoleh melalui akses internet website perusahaan terkait ataupun melalui mesin pencari lainnya. Sumber data dari penelitian ini diambil dari annual report perusahaan yang terdaftar dalam Bursa Efek Indonesia tahun 2009-2012, Peraturan Badan Pengawas Pasar Modal dan Lembaga Keuangan (Bapepam-LK) No. X.K.6 tentang Kewajiban Penyampaian Laporan Tahunan bagi Emiten dan Perusahaan Publik.

Data yang digunakan dalam penelitian ini adalah data sekunder, maka metode pengumpulan data yang digunakan adalah metode dokumentasi dengan cara menghimpun informasi yang berkaitan dengan voluntary nonfinancial disclosure didalam annual report dan informasi lainnya yang mampu mendukung penelitian kemudian mempelajari informasi tersebut untuk menyelesaikan masalah.

\section{Variabel dan Pengukuran Variabel}

Variabel dependen dalam penelitian ini adalah voluntary nonfinancial disclosure dan variabel independen dalam penelitian ini adalahpublic ownership, foreign ownership, tax disclosure, size dan asset turn over. Selain itu dalam penelitian ini juga menggunakan variabel kontrol yaitu leverage, profitability dan auditor. Lebih lanjut variabel dijelaskan dalam tabel 1.

\section{ANALISIS DATA DAN PEMBAHASAN}

Analisis data dalam penelitian ini menggunakan model analisis regresi berganda. Persamaan regresi yang digunakan adalah sebagai berikut ini:

VND: $\alpha+\beta_{1}$ FOROWN $+\beta_{2}$ PUBOWN + $\beta_{3}$ TAXDISC $+\beta_{4}$ SIZE $+\beta_{5}$ ATO + $\beta_{6} \mathrm{LEV}+\beta_{7}$ PROFIT $+\beta_{8}$ AUDIT $+\varepsilon$

Keterangan:

VND : Voluntary Nonfinancial Disclosure $\beta_{1}, \beta_{2}, \beta_{3}, \beta_{8}$ : Koefisienregresi

$\varepsilon \quad$ : Errors

FOROWN : Foreign Ownership

PUBOWN : Public Ownership

FAMOWN : Family ownership

TAXDISC : Tax Disclosure

SIZE : Ukuran perusahaan

ATO : Asset turnover

LEV : leverage

PROFIT : profitability

AUDIT : Auditor (Bigfour dan Non-Bigfour)

\section{Statistik Deskriptif}

Statistik deskriptif memberikan gambaran secara umum atas data yang digunakan dalam penelitian ini meliputi nilai minimum, ratarata dan standar deviasi. Hasil statistik deskriptif disajikan dalam tabel 2.

Tabel 1: Variabel dan Pengukuran Varibel

\begin{tabular}{|c|c|c|}
\hline Nama & Akronim & Pengukuran \\
\hline $\begin{array}{l}\text { Variabel Dependen } \\
\text { Voluntary Nonfinancial } \\
\text { Disclosure }\end{array}$ & VND & $\begin{array}{l}\text { Jumlah Saham Yang Dimiliki Manajer/Total Saham } \\
\text { Perusahaan }\end{array}$ \\
\hline $\begin{array}{l}\text { Variabel Independen } \\
\text { Foreign Ownership }\end{array}$ & FOROWN & $\begin{array}{l}\text { Jumlah Saham Yang Dimiliki asing/Total Saham } \\
\text { Perusahaan }\end{array}$ \\
\hline Public Ownership & PUBOWN & $\begin{array}{l}\text { Jumlah Saham Yang Dimiliki publik/Total Saham } \\
\text { Perusahaan }\end{array}$ \\
\hline Tax Disclosure & TAXDISC & $\begin{array}{l}\text { Skor tax disclosure yang dicapai/skor tax disclosure } \\
\text { maksimal }\end{array}$ \\
\hline size & SIZE & Log total asset \\
\hline Asset Turnover & ATO & Total penjualan/total asset \\
\hline Leverage & Leverage & Total liabilitas/total aset. \\
\hline Profitability & Profitability & Laba bersih/total asset \\
\hline Auditor & Auditor & Variabel dummy, skor $1=$ big four, skor $0=$ non big four \\
\hline
\end{tabular}


Hasil statistik deskriptif pada tabel 2 menunjukkan bahwa penelitian ini menggunakan sampel 408 sampel. Rata-rata level voluntary nonfinancial disclosure pada perusahaan perusahaan yang terdaftar di Bursa Efek Indonesia adalah 39\%. Level disclosure paling tinggi diraih oleh PT Bakrieland Development pada level 79\%, sedangkan level paling rendah diraih oleh PT Majapahit Securities pada level 20\%. Dalam penelitianya Doughlas et al. (2004), memaparkan bahwa domisili perusahaan mempengaruhi level pelaporan sosial dan lingkungan. Perusahaan yang berdomisili di wilayah dengan tingkat sosial maju cenderung lebih luas dalam menginformasikan pelaporan sosial dan lingkungan.

Public ownership mempunyai rata-rata $28 \%$ dan kepemilikan tertinggi adalah $100 \%$. Foreign ownership mempunyai rata-rata $24 \%$ dan kepemilikan tertinggi adalah $99 \%$. Sedangkan, level tax disclosure mempunyai rata-rata $76 \%$, level ini diraih cukup tinggi dikarenakan tax disclosure merupakan bagian dari mandatory disclosure pada perusahaan yang terdaftar di BEI.

Dalam penelitian ini, variabel dependen yang digunakan adalah voluntary nonfinancial disclosure yang diukur dengan voluntary nonfinancial disclosure index (VNDI) yang diadaptasi dari Meek et al.
(1995), Eng dan Mak (2003), Gisbert dan Navallas (2013) dan Global Report Initiative (GRI) yang dieliminasi kembali dengan adanya mandatory disclosure yang tertuang dalam peraturan yang diwajibkan Bapepam. Voluntary Nonfinancial Disclosure index (VNDI) dalam penelitian ini dibagi kedalam 4 sub kategori yaitu strategic disclosure, employee disclosure, social disclosure dan envinronment discosure. Total indeks yang dihasilkan adalah 56 item. Statistik deskriptif untuk voluntary nonfinancial disclosure dapat dilihat pada tabel 3 dan grafik 1 .

Berdasarkan tabel 3 dan grafik 1 statistik deskriptif diatas menunjukan tingkat voluntary nonfinancial disclosure pada perusahaan yang terdaftar di BEI memiliki ratarata $39,6 \%$. Tingkat voluntary nonfinancial disclosure setiap tahun mengalami peningkatan walaupun peningkatannya hanya kecil, yaitu pada tahun 2009 tingkat voluntary nonfinancial disclosure adalah 38\%, 39\% pada tahun 2010, 40\% pada tahun 2011 dan $41 \%$ pada tahun 2012. Kenaikan tersebut dapat terjadi dikarenakan kesadaran perusahaan di Indonesia untuk melakukan voluntary nonfinancial disclosure telah meningkat. Perusahaan di Indonesia telah menyadari akan pentingnya melakukan voluntary nonfinancial disclosure.

Tabel 2: Hasil Statistik Deskriptif

\begin{tabular}{lcrrrr}
\hline & $\mathrm{N}$ & Minimum & \multicolumn{1}{c}{ Maximum } & \multicolumn{1}{c}{ Mean } & Std. Deviation \\
\hline FOROWN & 408 &, 0000 &, 9900 &, 244320 &, 3132506 \\
PUBOWN & 408 &, 0000 & 1,0000 &, 285333 &, 2051262 \\
TAXDISC & 408 &, 6000 & 1,0000 &, 762745 &, 0874667 \\
SIZE & 408 & 4,3273 & 8,8032 & 6,518225 &, 8797187 \\
ATO & 408 &,- 3515 & 31,9878 &, 847963 & 2,0277129 \\
LEV & 408 &, 0057 & 27,1341 &, 696406 & 1,5281194 \\
PROFIT & 408 &,- 4480 & 6,1628 &, 094852 &, 3439190 \\
VND & 408 & .1964 & .7857 & .396008 & .0998658 \\
Valid N (Listwise) & 408 & & & & \\
\hline
\end{tabular}

Keterangan: FOROWN $=$ Foreign Ownership, PUBOWN $=$ Public Ownership, TAXDISC $=$ Tax Disclosure, SIZE $=$ Ukuran perusahaan, ATO $=$ Asset Turnover, Leverage $=$ Leverage, Profitability $=$ profitability, $\mathrm{VND}=$ Voluntary Nonfinancial Disclosure

Sumber: Hasil pengolahan data 
Tabel 3: Empat Sub Kategori VNDI

\begin{tabular}{lccccc}
\hline & Average & 2009 & 2010 & 2011 & 2012 \\
\hline Strategic Disclosure & $59,75 \%$ & $59,2 \%$ & $59,7 \%$ & $60 \%$ & $60,1 \%$ \\
Employee Disclosure & $36,45 \%$ & $35,6 \%$ & $36,5 \%$ & $36,7 \%$ & $37 \%$ \\
Environment Disclosure & $28,12 \%$ & $28,2 \%$ & $27,9 \%$ & $28,1 \%$ & $28,3 \%$ \\
Social Disclosure & $31,17 \%$ & $30,1 \%$ & $30,4 \%$ & $32,1 \%$ & $32,1 \%$ \\
\hline Total VNDI & $\mathbf{3 9 , 6 \%}$ & $\mathbf{3 8 \%}$ & $\mathbf{3 9 \%}$ & $\mathbf{4 0 \%}$ & $\mathbf{4 1 \%}$ \\
\hline
\end{tabular}

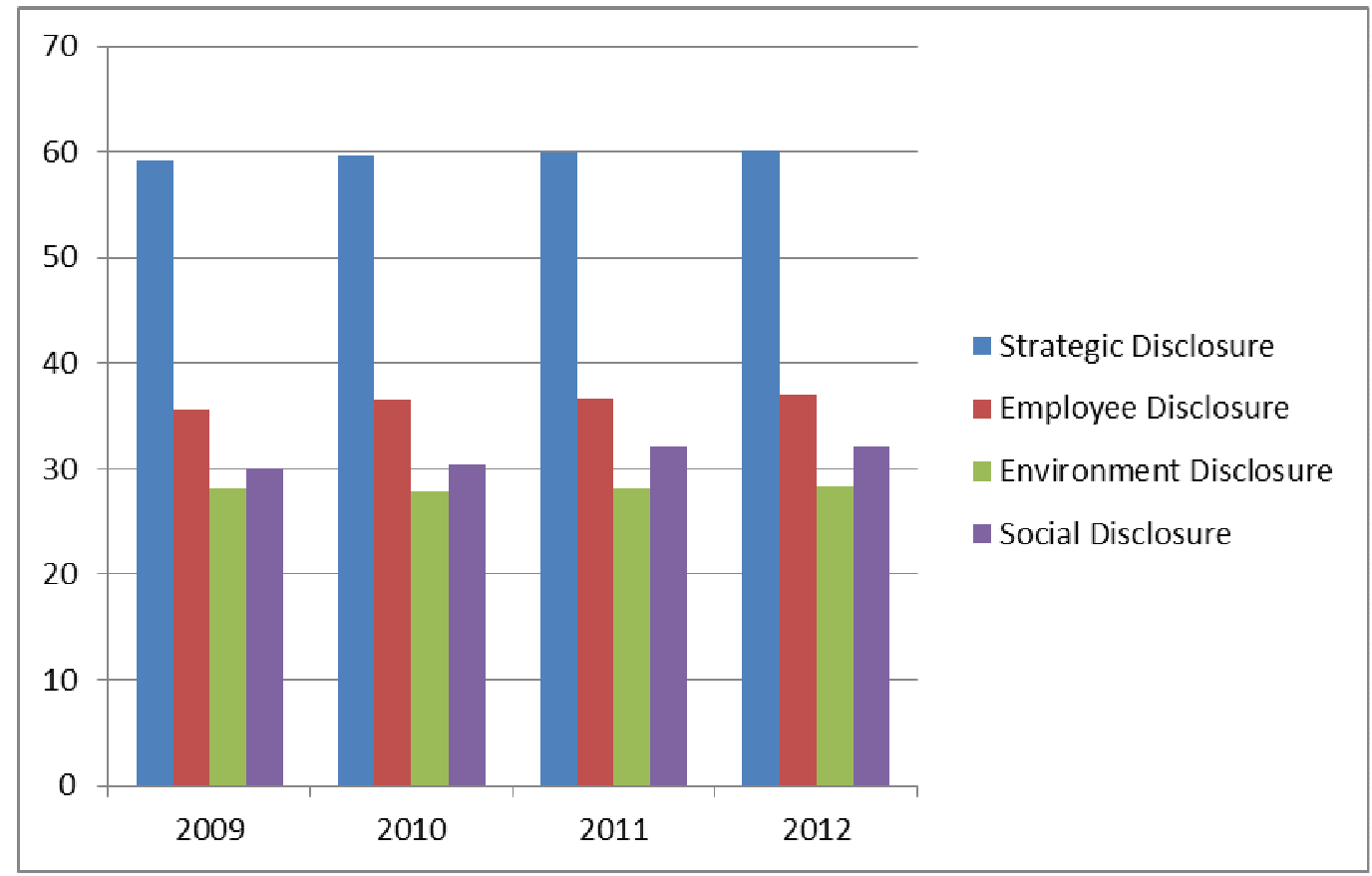

Grafik 1: Perubahan Tiap Tahun

Tabel 3 juga menunjukkan bahwa strategic disclosure $(59,2 \%$ - 60,1\%) merupakan sub kategori yang memiliki skor tertinggi dan paling banyak diungkapkan, sedangkan environment disclosure $(27,9 \%$ - 28,3\%) memiliki skor terendah jika dibandingan dengan lima sub kategori lainnya.

Grafik perubahan sub kategori VNDI menunjukan strategic disclosure memiliki rata-rata paling tinggi yaitu $59,75 \%$, hal tersebut dikarenakan perusahaan akan cenderung menampilkan strategi perusahaan yang lebih lengkap dan mendetail untuk menarik investor dari luar. Environment disclosure memiliki nillai disclosure yang paling rendah yaitu ratarata $28,12 \%$, perusahaan masih banyak yang belum mengungkapakan hal-hal mengenai environment. Indonesia sebagai negara yang berkembang memang memiliki tingkat disclo- sure yang lebih rendah jika dibandingkan dengan negara maju.

\section{Pembahasan}

Pengujian hipotesis dalam penelitian ini menggunakan model regresi berganda dengan hasil pengujian yang sajikan dalam tabel 4 . Berdasarkan tabel 4 di bawah ditunjukkan bahwa nilai probability value (sig) sebesar 0.000 yang beratilebih kecil dari 5\% sehingga dapat dinyatakan bahwa model regresi layak (fit) untuk digunakan sebagai model dalam penelitian ini. Nilai adjusted $R^{2}$ adalah 0.544 mengindikasikan bahwa variabel voluntary nonfinancial disclosure (VND) mampu dijelaskan oleh variabel independen berupa FOROWN, PUBOWN, TAXDISC, SIZE dan ATO sebesar 54\% dan sisanya yaitu sebesar $46 \%$ dijelaskan oleh variabel lain di luar model penelitian ini. 
Tabel 4: Hasil Uji Regresi Berganda

\begin{tabular}{lcc}
\hline \multicolumn{1}{c}{ VariabelIndependen } & Coefficient & \\
\hline Constant &,- 304 & Probability \\
FOROWN &, 025 &, 000 \\
PUBOWN &, 090 &, $030^{* *}$ \\
TAXDISC &, 652 &, $000^{*}$ \\
SIZE &, 026 &, $000^{*}$ \\
ATO &, 020 &, $000^{*}$ \\
Leverage &,- 026 &, $000^{*}$ \\
Profitability &, 012 &, $000^{*}$ \\
AUDIT &, 004 &, 613 \\
squared & &, 678 \\
Adj. $R$-squared & &, 553 \\
Prob. (F-statistic) & &, 544 \\
\hline Keteran: FOROWN & 0.000 \\
\hline
\end{tabular}

Keterangan: FOROWN $=$ Foreign Ownership, PUBOWN $=$ Public Ownership, TAXDISC $=$ Tax Disclosure, SIZE $=$ Ukuranperusahaan, $\mathrm{ATO}=$ Asset Turnover, Leverage $=$ Leverage, Profitability $=$ profitability, AUDIT $=$ Auditor, VND $=$ Voluntary Nonfinancial Disclosure

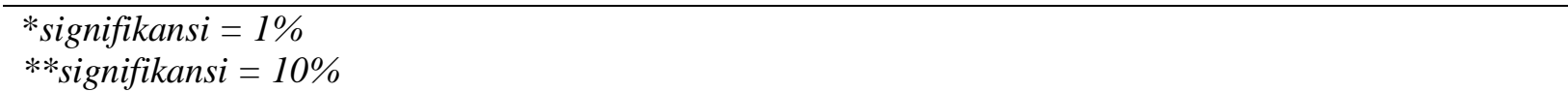

Sumber: data sekunder yang diolah

Berdasarkan tabel 4 diatas, pengujian hipotesis menunjukan bahwa foreign ownership, public ownership, tax disclosure, size dan asset turnover berpengaruh terhadap level voluntary nonfiancial disclosure.

Foreign ownership memiliki nilai signifikansi 0,030 sehingga lebih kecil dari 0,05 dan dapat diartikan bahwa foreign ownership memiliki pengaruh signifikan terhadap voluntary nonfinancial disclosure. Koefisien regresi dari foreign ownership adalah sebesar 0,025, karena menunjukan nilai yang positif maka foreign ownership berpengaruh positif terhadap voluntary nonfiancial disclosure. Berdasarkan nilai signifikansi tersebut dapat disimpulkan bahawa hipotesis 1 diterima. Hassan (2013) berpendapat bahwa kehadiran foreign ownership sebagai aspek mekanisme kepemilikan dapat diindikasi menyebabkan meningkatkan tingkat voluntary disclosure. Peningkatan foreign ownership pada perusahaan diharapkan dapat meningkatkan penyediaan informasi yang berkualitas dan dapat memotivasi manajer untuk memberikan informasi tambahan terkait dengan voluntary disclosure. Foreign ownership pada perusahaan di Indonesia akan melakukan monitoring atas kinerja manajer secara ketat, hal terebut dikarenakan manajer akan berusaha untuk memuaskan pemegang saham asing untuk mendapatkan insentif yang besar dan manajer akan lebih berhati-hati dalam bekerja karena adanya perbedaan budaya, bahasa dan letak goegrafis antara perusahaan dan pemegang saham.

Public ownership memiliki nilai signifikansi 0,000 sehingga lebih besar dari 0,05 dan dapat diartikan bahwa public ownership memiliki pengaruh terhadap voluntary nonfinancial disclosure. Koefisien regresi dari public ownership adalah sebesar 0,090, karena menunjukan nilai yang positif maka public ownership berpengaruh positif terhadap voluntary nonfinancial disclosure. Berdasarkan nilai signifikansi tersebut dapat disimpulkan bahwa hipotesis 2 diterima. Hardiningsih (2008) mengemukakan bahwa adanya perbedaan dalam proporsi saham yang dimiliki oleh masyarakat dapat mempengaruhi kelengkapan pengungkapan oleh perusahaan. Hal ini karena semakin banyak pihak yang membutuhkan informasi tentang perusahaan, semakin banyak pula detail-detail butir yang dituntut untuk dibuka dan dengan demikian pengungkapan perusahaan semakin luas. 
Tax disclosure memiliki nilai signifikansi 0,000 sehingga lebih kecil dari 0,05 dan dapat diartikan bahwa tax disclosure memiliki pengaruh sangat signifikan terhadap voluntary nonfinancial disclosure. Koefisien regresi dari tax disclosure adalah sebesar 0,652, karena menunjukan nilai yang positif maka tax disclosure berpengaruh positif terhadap voluntary nonfinancial disclosure. Berdasarkan nilai signifikansi tersebut dapat disimpulkan bahwa hipotesis 3 diterima. Hasill tersebut sejalan dengan penelitian yang dilakukan oleh Taylor et al (2011) yang menunjukan bahwa withholding taxes berpengaruh positif dan berhubungan terhadap pola disclosure. Berdasarkan hal tersebut dapat ditarik kesimpulan bahwa struktur pajak dapat mempengaruhi pola corporate disclosure. Tax disclosure di Indonesia merupakan bagian dari mandatory disclosure yang dikeluarkan oleh BapepamLK no X.K.6. Lundholm (2003) berpendapat bahwa meskipun mandatory disclosure adalah melihat ke belakang dan karena itu tidak memiliki konten informasi, namun meningkatkan kualitas voluntary disclosure.

Size memiliki nilai signifikansi 0,000 sehingga lebih kecil dari 0,05 dan dapat diartikan bahwa tax disclosure memiliki pengaruh sangat signifikan terhadap voluntary nonfinancial disclosure. Koefisien regresi dari Size adalah sebesar 0,026, karena menunjukan nilai yang positif maka Size berpengaruh positif terhadap voluntary nonfinancial disclosure. Berdasarkan nilai signifikansi tersebut dapat disimpulkan bahwa hipotesis 4 diterima. Hasil ini sejalan dengan penelitian Meek el al. (1995). Hal ini biasanya dikaitkan dengan agency theory yang menyatakan bahwa semakin besar suatu perusahaan maka biaya keagenan yang muncul juga semakin besar. Untuk mengurangi biaya keagenan tersebut, perusahaan akan cenderung mengungkapkan informasi yang lebih luas. Perusahaan besar berdampak lebih besar terhadap masyarakat dan oleh karena itu biasanya memiliki stakeholder yang lebih banyak sehingga memberikan tekanan yang lebih besar pula kepada perusahaan (Knox et al. 2005). Selain itu, perusahaan besar memiliki sumber daya yang memadai untuk mengumpulkan, menganalisis, dan menyajikan data terkait aktivitas keberlanjutan (Oliveira 2010). Dengan meningkatkan volutary nonfinancial disclosure, seperti kepedulian pada lingkungan melalui pelaporan keuangan, maka perusahaan dalam jangka waktu panjang bisa terhindar dari biaya yang sangat besar akibat dari tuntutan masyarakat.

Asset turn over memiliki nilai signifikansi 0,000 sehingga lebih kecil dari 0,05 dan dapat diartikan bahwa tax disclosure memiliki pengaruh sangat signifikan terhadap voluntary nonfinancial disclosure. Koefisien regresi dari Asset turn over adalah sebesar 0,020, karena menunjukan nilai yang positif maka Asset turn over berpengaruh positif terhadap voluntary nonfinancial disclosure. Berdasarkan nilai signifikansi tersebut dapat disimpulkan bahwa hipotesis 5 diterima. Asset turn over merupakan rasio yang digunakan untuk mengukur seberapa efisiensi seluruh aktiva perusahaan digunakan untuk menunjang kegiatan penjualan (Van Horne dan Wachowicz 2007). Menurut Ang et al. (2000) rasio asset turn over dapat mengukur bagaimana efektifitas persusahaan dalam mengelola aset perusahaan. Perusahaan dengan rasio assetturn over yang rendah menunjukan agency cost yang positif (Ang et al.2000).

\section{PENUTUP \\ Simpulan}

Berdasarkan hasil penelitian dapat disimpulkan bahwa foreign ownership, public owner ship, tax disclosure, size dan asset turnover berpengaruh terhadap level voluntary nonfinancial disclosure. Penelitian ini juga menunjukan bahwa model prediksi yang dikembangkan dalam penelitian ini adalah fit untuk digunakan sebagai model penelitian untuk menentukan determinan voluntary nonfinancial disclosure dengan latar perusahaan listed di Indonesia. Foreign ownership yang tinggi di Indonesia akan dapat meningkatkan level voluntary nonfinancial disclosure karena foreign ownership akan lebih ketat dalam hal monitoring terhadap manajer dan public ownership yang merupakan kepemilikan saham oleh masyarakat maka tingkat kebutuhan akan informasi akan meningkat sehingga voluntary 
nonfinancial disclosure akan meningkat pula. Tax disclosure yang bertambah akan menyebabkan voluntary nonfinancial disclosure juga akan bertambah, hal tersebut dikarenakan perusahaan akan berusahaa mengungkapkan hal yang diwajibkan terlebih dahulu sebelum melakukan voluntary nonfinancial disclosure. Size berpengaruh positif terhadap voluntary nonfinancial disclosure karena dengan meningkatkan volutary nonfinancial disclosure, seperti kepedulian pada lingkungan melalui pelaporan keuangan, maka perusahaan dalam jangka waktu panjang bisa terhindar dari biaya yang sangat besar akibat dari tuntutan masyarakat. Asset turnover berpengaruh positif terhadap voluntary nonfinancial disclosure karena asset turnover merupakan cara untuk melihat efektifitas manajer dalam mengelola aset perusahaan.

Rerata level voluntary nonfinancial disclosure perusahaan yang terdaftar di BEI adalah sebesar $39,6 \%$, sehingga dapat disimpulkan bahwa kesadaran perusahaan-perusahaan di Indonesia dalam praktik voluntary nonfinancial disclosure masih rendah jika dibandingkan negara maju. Hal tersebut dikarenakan Indonesia merupakan negara berkembang sehingga praktik voluntary nonfinancial disclosure di Indonesia masih rendah.

Implikasi dari penelitian ini menunjukkan adanya variasi tingkat voluntary nonfinancial disclosure pada perusahaan yang terdaftar di BEI dari waktu ke waktu. Perusahaan akan berusaha menambah voluntary nonfinancial disclosure untuk mendapatkan nilai perusahaan yang baik sehingga dapat menarik investor. Investor tidak hanya melihat informasi financial saja, namun juga akan melihat informasi mengenai lingkungan dan sosial yang tertuang dalam informasi nonfinancial.

Penelitian ini dilakukan dengan berbagai keterbatasan yang dapat mempengaruhi hasil penelitian. Adapun keterbatasan dalam penelitian ini adalah dalam hal penilaian level voluntary nonfinancial disclosure menggunakan teknik scoring dengan bobot yang sama pada setiap item dalam voluntary nonfinancial disclosure perusahaan, sehingga tidak ada perbedaan score antara perusahaan yang mengungkapkan secara mendetail dan perusahaan yang mengungkapkan secara tidak mendetail.

\section{DAFTAR PUSTAKA}

Ahmed, H. J. A. 2009. Managerial ownership concentration and agency conflict using logistic regression approach: Evidence from Bursa Malaysia. Journal of Management Research 1 (1): 1-10.

Alchian, A. A., dan S. Woodward. 1988. Review: The Firm is dead: Long live the firm a review of Oliver $E$. Williamson's The Economic Institutions of Capitalism. Journal of Economic Literature26 (1): 65-79.

Ang, J., R. Cole., dan J. Lin. 2000. Agency costs and ownership structure. The Journal of Finance 55 (1): 81-106.

Barako, D. G. 2007. Determinants of voluntary disclosures in Kenyan companies annual reports. African Journal of Business Management 1 (5): 113-128.

Battacherjee, A. 2012. Social science research: Principles, methods and practices Creative Commons Attribution NonCommercial Share A-like 3.0 Unported License.

Beattie, V., B. McInnes., dan S. Fearnley. 2004. A methodology for analysing and evaluating narrative in annual reports: A comprehensive descriptive profile and metrics for disclosure quality attributes. Accounting Forum 28: 205-236.

Berle, A., dan G. Means. 1932. The modern corporation and private property. New York: Macmillan.

Chau, G. K., dan S. Gray. 2002. Ownership structure and corporate voluntary disclosure in Hong Kong and Singapore. The International Journal of Accounting 37 (2): 247-265. 
Chau, G., dan S. Gray. 2010. Family ownership, board independence and voluntary disclosure: Evidence from Hong Kong. Journal of International Accounting Auditing \& Taxation 19 (2): 93-109.

Colgan, P. M. 2001. Agency theory and corporate governance: Review of the literature from a UK perspective 2001.

Diyanti, F. 2010. Mekanisme good corporate governance, karakteristik perusahaan dan mandatory disclosure: Studi empiris pada perusahaan manufaktur yang terdaftar di bursa efek Indonesia. Fakultas Ekonomi Universitas Brawijaya.

Eichfelder, S., dan C. Kegels. 2012. Tax compliance costs caused by agency action? Empirical evidence and implications for tax compliance. Schumpeter Discussion Paper (University of Wuppertal).

Eng, L. L., dan Y. T. Mak. 2003. Corporate governance and voluntary disclosure. Journal of Accounting and Public Policy 22 (4): 325-345.

Fama, E., dan M. Jensen. 1983. Separation of ownership and control. The Journal of Law and Economics 26 (2): 301- 325.

Gisbert, A., dan B. Navallas. 2013. The association between voluntary disclosure and corporate governance in the presence of severe agency conflicts. Advances in Accounting, incorporating Advances in International Accounting.

Govindarajan, V., dan R. N. Anthony. 2001. Management Control System. Jakarta: Salemba Empat.

Hardiningsih, P. 2008. Analisis faktor-faktor yang mempengaruhi voluntary disclosure laporan tahunan perusahaan. Jurnal Bisnis dan Ekonomi (JBE) 15 (1): 67-79.

Hassan, M. K. 2013. Corporate Governance Characteristics and Voluntary Disclo- sure: The case of UAE listed corporations. The 2013 IBEA, International Conference on Business, Economics, and Accounting 20 - 23 March 2013 Bangkok - Thailand.

Hassan, O. A. G., G. Giorgioni., P. Romilly., dan D. M. Power. 2011. Voluntary disclosure and risk in an emerging market. Journal of Accounting in Emerging Economies 1 (1): 33-52.

Healy, P. M., dan K. G. Palepu. 2001. Information asymmetry, corporate disclosure, and the capital markets: A review of the empirical disclosure literature. Journal of Accounting \& Economics 31 (1): 405-440.

Ho, P. L., dan G. Taylor. 2013. Corporate governance and different types of voluntary disclosure evidence from Malaysian listed firms. Pacific Accounting Review 25: 4-29.

Jensen, M. C., dan W. H. Meckling. 1976. Theory of the firm: Managerial behavior, agency costs and ownership structure. Journal of Financial Economics 3 (4): 305-360.

Khan, I. 2012. The impact of ownership structure on voluntary corporate disclosure in annual reports: Evidence from Fiji. Accounting \& Taxation 5 (1): 47-58.

Knox, S., S. Maklan., dan P. French. 2005. Corporate social responsibility: Exploring stakeholder relationships and programme reporting across Leading FTSE Companies. Journal of Business Ethics61: 7 -28.

Lang, M. H., dan R. Lundholm. 1996. Corporate disclosure policy and analyst behavior. Accounting Review 71 (4).

Lundholm, R. 2003. Historical accounting and the endogenous credibility of current disclosures. Journal of Accounting, Auditing and Finance 18: 207-229. 
Meek, G. K., C. B. Roberts., dan S. J. Gray. 1995. Factors influencing voluntary annual report disclosures by US, UK and continental European multinational corporations. Journal of International Business Studies 26 (3): 555-572.

Mirfazli, E. 2008. Corporate social responsibility (CSR) information disclosure by annual report of public companies listed at Indonesia Stock Exchange (IDX). International Journal of Islamic and Middle Eastern Finance and Management 1 (4): 275-284.

Oliveira, L. 2010. Intellectual Capital Reporting in Sustainability Reports. Journal of Intellectual Capital 11 (4): 575-594.

Probohudono, A. N., G. Tower., dan Rusmin. 2013a. Diversity in risk communication. Australasian Accounting Business \& Finance Journal 7 (1): 4358.

Probohudono, A. N., G. Tower, dan R. Rusmin. 2013b. Risk disclosure during the global financial crisis. Social Responsibility Journal 9 (1): 124-137.

Robb, S. W. G., E. Single. L, dan M. T. Zarzeski. 2001. Nonfinancial disclosure accros Anglo-American countries. Journal of International Accounting, Auditing \& Taxation 10: 71-83.

Schuster, P., dan V. O'Connell. 2006. The trend towards voluntary disclosures. Management Accounting Quarterly 7 (2): 1-9.

Scott, W. R. 2003. Financial accounting theory. Toronto: Prentice Hall International Inc.
Su, Z., Y. Li, dan L. Li. 2010. Ownership concentration and executive compensation in emerging economies: $E$ vidence from China. Corporate Governance 10 (3): 223-233.

Taylor, G. J. 2008. Determinants of financial instrument disclosure pattern of Australian listed resource firms preand post- IFRS adoption. Unpublised Doctoral Thesis, Curtin University of Technology, Perth Australia.

Taylor, G., G. Tower, dan M. V. D. Zahn. 2011. The influence of international taxation structures on corporate financial disclosure patterns. $A c$ counting Forum 35: 32-46.

Ugurlu, M. 2000. Agency costs and corporate control devices in the Turkish manufacturing industry. Journal of Economic Studies 27 (6): 566-599.

Van Horne, J. C., dan J. M. Wachowicz. 2007. Fundamentals of financial: Manajemen prinsip-prinsip manajemen keuangan. Penerjemah: Dewi Fitriasari dan Deny Arnos Kwary. Jakarta: Penerbit Salemba Empat.

Wallace, R.S.O., Naser, K., dan A. Mora. 1994. The relationship between the comprehensiveness of corporate annual reports and firm characteristics in Spain. Accounting and Business Research 25 (97): 41-53.

Zhegal, D., dan S. A. Ahmed. 1990. Comparison of social responsibility information disclosure media used by Canadian firms. Accounting, Auditing \& Accountability Journal 3 (1). 